\title{
Stamina of a non-gasketed flange joint under combined internal pressure and axial loading
}

\author{
M Abid ${ }^{1 *}$, A W Awan ${ }^{1}$, and D H Nash ${ }^{2}$ \\ ${ }^{1}$ Faculty of Mechanical Engineering, Ghulam Ishaq Khan Institute of Engineering Sciences and Technology, \\ Topi, NWFP, Pakistan \\ ${ }^{2}$ Department of Mechanical Engineering, University of Strathclyde, Glasgow, UK
}

The manuscript was received on 14 February 2008 and was accepted after revision for publication on 2 June 2008.

DOI: 10.1243/09544089JPME212

\begin{abstract}
The performance of a bolted flange joint is characterized mainly by its 'strength' and 'sealing capability'. A number of numerical and experimental studies have been conducted to study these characteristics under internal pressure loading conditions alone. However, limited work is found in the literature under conditions of combined internal pressure and axial loading. The effect of external, axial loading pressure being unknown, the optimal performance of the bolted flange joint cannot be achieved. Current design codes do not address the effects of axial loading on structural integrity and sealing ability. To study joint strength and sealing capability under combined loading conditions, an extensive experimental and numerical study of a nongasketed flange joint was carried out. Actual joint load capacity was determined at both design and test stages with the maximum external axial loading that can be applied for safe joint performance. Experimental and numerical results have been compared and overall joint performance and behaviour is discussed in detail.
\end{abstract}

Keywords: non-gasketed, combined, bolt-up, operating, axial, sealing, strength

\section{INTRODUCTION}

Different types of flange joints evolved over the centuries and were used at a low pressure and kept in room temperatures. However, high-pressure, hightemperature, and different external loading applications led to sealing problems. Leakages (small and large) in flange joints is a perennial safety concern for human lives, environmental effect, and cost. With rapid technological advances in high-pressure, hightemperature, and external loading applications, trends are changing. A flange joint must have adequate mechanical strength and good leak tightness, therefore it is important to evaluate integrity and sealing performance in actual operating conditions. Available design rules $[\mathbf{1}, \mathbf{2}]$ for flange joints are mainly concerned with the strength of flanges and do not sufficiently consider their sealing. In addition, they do not address the effect of any external loading on integrity and sealing performance. Non-gasketed flange joints are considered as an alternative to the 'static mode of load' under bolt-up and internal pressure applications, [3-8] and bolt-up and different temperature loading conditions $[\mathbf{9}, \mathbf{1 0}]$ and its better joint strength and sealing capabilities. External loading on bolted flange joints have been discussed $[\mathbf{1 1}, \mathbf{1 2}]$ but these studies are for gasketed flange joints and bending loading.

In this study, a detailed three-dimensional nonlinear finite-element analysis (FEA) of a non-gasketed flange joint with a positive taper angle on the flange sealing area is performed to study its 'joint strength' and 'sealing capability' under different internal pressure and axial loading conditions. The level and distribution of different stress magnitudes and its variation are used to quantify joint strength. Contact or interface pressure variation is used as the main quantitative measure of its sealing ability. In addition, to determine actual joint capacity at optimal operating conditions, i.e. for safe stress and no-leak conditions, the joint is further analysed at varied pressures at the design and proof test stages and at $100 \mathrm{~N}-640 \mathrm{kN}$ for internal pressure plus axial loading. 


\section{ALLOWABLE STRESSES AND FLANGE JOINT CONFIGURATION}

Allowable stresses and material properties for flange, pipe, and bolt and symmetry plate are given in Table 1 . The material properties for the flange is as per ASTM A105 [13] and for the bolt and washer as per ISO898, class 8.8 [14]. Bilinear kinematic hardening for elastoplastic material properties is used during the analysis. A bilinear material model consists of two sections each having a linear gradient. In the elastic region up to the yield stress the gradient of the stress-strain curve is Young's modulus of elasticity. Beyond the yield stress, the gradient (plastic modulus) is 10 per cent $[4,15]$ of Young's modulus. The flange dimensions are: thickness $30 \mathrm{~mm}$, taper angle $=0.03^{\circ}$, number of bolts $=16$, and bolt diameter $10 \mathrm{~mm}$. A flange joint equivalent to 4 nominal bore of 900\# class is used in the present study.

\section{FINITE-ELEMENT MODELLING}

In the present work, a detailed three-dimensional parametric finite element (FE) model developed in reference [9] is used, as it eliminates the need for simplifications, such as removing the effects

Table 1 Material properties

\begin{tabular}{llll}
\hline Non-gasketed joint & $E(\mathrm{MPa})$ & $v$ & Allowable stress (MPa) \\
\hline Flange/pipe & 203395 & 0.3 & $248.2\left(2 / 3 \mathrm{rd} \sigma_{y}\right)$ \\
$\begin{array}{l}\text { Bolt (ISO 898, } \\
\quad \text { class 8.8) }\end{array}$ & 204000 & 0.3 & 640 \\
\begin{tabular}{l} 
Washer \\
\hline
\end{tabular} & 204000 & 0.3 & 640 \\
\hline
\end{tabular}

associated with the bolt hole. Fully parametric models are used throughout the study, so that the time involved in building scaled models of different geometries could be minimized. An angular portion $\left(11.25^{\circ}\right.$ rotation of main profile or $1 / 32$ part) of the flange is modelled based on symmetry with a bolt hole at the required location. The second flange is replaced by a symmetry plate. The resulting flange joint model with its boundary conditions is shown in Fig. 1(a). ANSYS [16] software was used for FEA analysis.

\subsection{Element selection and mesh}

As stresses in flange, bolt, washer, and symmetry plate are the required outputs, two classes of elements are used.

Solid structural elements. Solid structural elements (SOLID45) are used for structural stress analysis of the flange joint.

Contact elements. Contact elements are used to model the contact between different surfaces of the joint. Three-dimensional surface-to-surface CONTA173 elements, in combination with TARGE170 target elements, are used to simulate contact distribution between the bottom face of the flange and the symmetry plate, and the top of the flange and the bottom of the washers.

Mesh. Mapped meshing is used in the regions of high-stress distribution i.e. flange fillet, bolt-hole, bolt head and shank corner, and symmetry plate, which are identified on the basis of preliminary studies of the model. A bolt and washer combined model has been developed. The front areas of the model are meshed first and then swept over the volumes for flange, bolt, and symmetry plate (Fig. 1(b)).

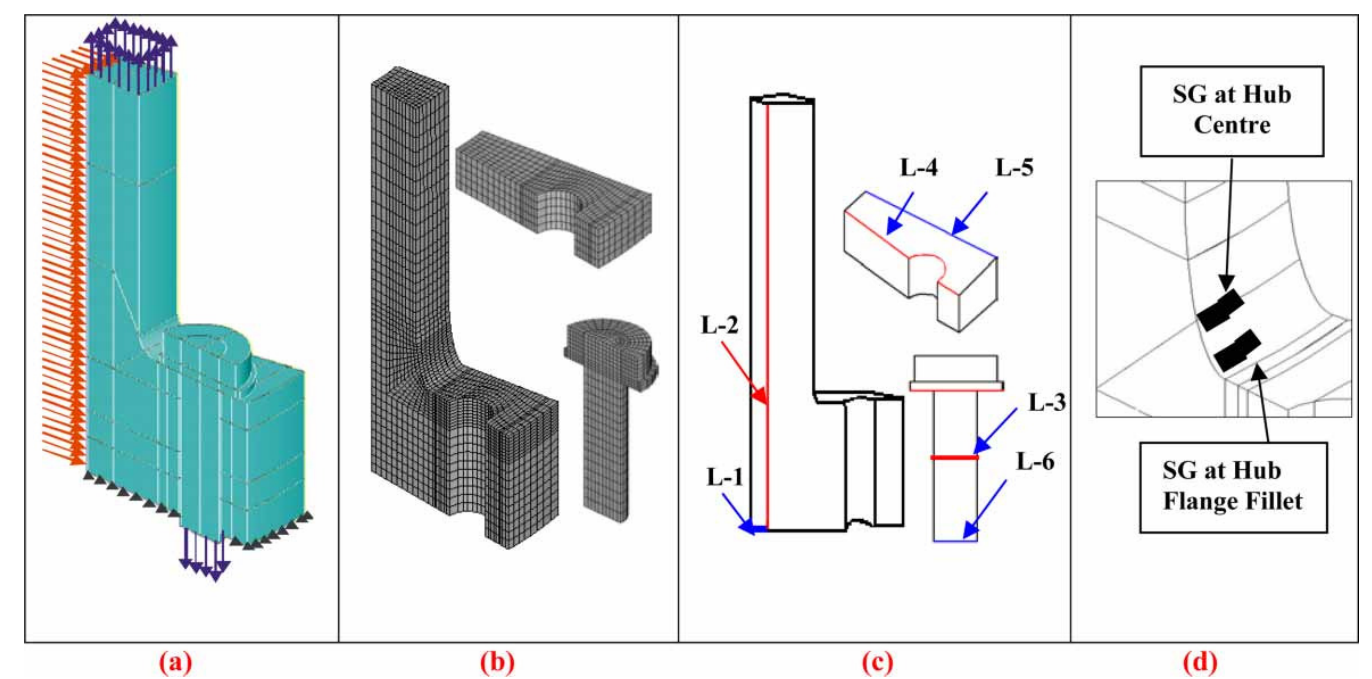

Fig. 1 (a) Three-dimensional model with boundary conditions, (b) mesh, (c) location for graphical results, and (d) zoom model for gauge location 


\subsection{Boundary conditions}

Internal pressure is applied at inside diameter of pipe and flange, and loading due to the head and additional axial loading is directly applied as nodal forces across the wall of the pipe.

The flanges are free to move in either axial or radial direction, providing flange rotation and permitting the observation of the exact nature of stress in flange, bolt, and symmetry plate. The symmetry plate is constrained in the axial direction ( $y$-direction) only, and is free to move either in radial or tangential direction. The bolt is constrained along the centre nodes at the bottom surface in $x$ - and $z$-directions and is free to elongate in the $y$-direction. Contact is defined between the top face of the flange ring and the bottom of the bolt head, bottom of the flange ring and top of the symmetry plate. This makes the problem complex. Contact analysis is also non-linear analysis due to non-linear behaviour, such as penetration and contact generation. In addition, in the present study, a nonlinear material model was used in order to simulate the realistic behaviour of the flange joint components. All these factors make the analysis non-linear. The first non-linear solution step is the contact initiation, the second and third steps occur in the non-linear material model. During the test, each load step was further divided into a number of small substeps, ranging from 10 to 1000 . The boundary conditions applied are shown in Fig. 1(a). For a complete understanding of the loading applied, the following multi-load step procedure was used.

Step 1: Contact initiation. Contact between flange top surface and washer bottom was defined by giving a small initial displacement of $U Y=-0.0025 \mathrm{~mm}$ in the axial direction to the bolt-bottom surface.

Step 2: Pre-stress application. A second value of UY = $-0.156 \mathrm{~mm}$ was applied to bolt's bottom surface, to achieve an initial pre-stress value of $474 \mathrm{MPa}$ in the bolt (which is 74 per cent of the yield stress of the bolt material) although the recommended value is 80 per cent of the yield stress [3-9].

Step 3: Internal pressure application. After pre-stress application, the design pressure of $15.3 \mathrm{MPa}$ and proof test pressure of $23 \mathrm{MPa}$ was applied separately for the two different cases. End-cap loading (21.48 and $32.29 \mathrm{MPa}$ in design and proof test pressures, respectively, due to internal pressure) was applied to the end of the pipe, a suitable distance away from the joint [3-9].

Step 4: Internal pressure plus axial load application. An axial load ranging from 100 to $640 \mathrm{kN}$ (23.33149.4 MPa) was applied in addition to the design pressure of $15.3 \mathrm{MPa}$ and proof test pressure of $23 \mathrm{MPa}$. Both the cases were analysed to further investigate the joint behaviour.

\section{FE MODEL VERIFICATION}

The FE model is verified mathematically at the pipe location. Whereas the FE model is verified with the experimental results at the pipe, hub centre, hubflange fillet, and bolt under the applied axial loading only (Table 2). Results are compared and are found in good agreement with an axial loading of $664 \mathrm{kN}$. The Three-dimensional FE model has already been verified by Abid et al. [9] under internal pressure loading only. Lame's theory is used at the pipe section, as the pipe used falls in the category of thick-walled cylinders [17].

\section{FE RESULTS DISCUSSION}

Stress and displacement results at the gauge location at pipe, hub centre, hub-flange fillet, maximum at hub, bolt-hole region, bolt (at gauge location and maximum anywhere), and symmetry plate under only axial loading and combined internal pressures plus axial loading are discussed. Graphically plotted results at various locations of the joint components are as given in Fig. 1(c). The hub region is shown in Fig. 1(d).

\subsection{Stress variation in pipe and flange}

\subsubsection{Stress intensity and axial stress in pipe}

Stress intensity and axial stress are found to be within the allowable stress values at all loading conditions i.e. internal pressure (design and proof test) plus axial loading ranging from 100 to $640 \mathrm{kN}$. FEA results are also found in good agreement with the experimental results (Fig. 2(a)).

Table 2 FE model verification: FEA versus experimental results

\begin{tabular}{llllll}
\hline & & & & \multicolumn{2}{c}{ Bolt (MPa) } \\
\cline { 6 - 7 } Results & Pipe (MPa) & $\begin{array}{l}\text { Hub centre } \\
(\mathrm{MPa})\end{array}$ & $\begin{array}{l}\text { Hub flange } \\
\text { fillet }(\mathrm{MPa})\end{array}$ & $\begin{array}{l}\text { Inside } \\
\text { node }\end{array}$ & $\begin{array}{l}\text { Outside } \\
\text { node }\end{array}$ \\
\hline FEA & 141.5 & 303 & 288 & 643 & 544 \\
Experimental & 141.0 & 332 & 310 & 658 & 433 \\
\hline
\end{tabular}




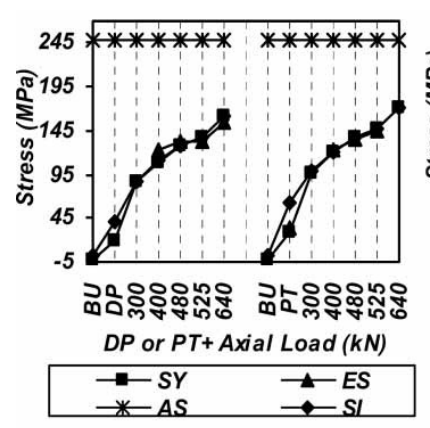

(a)

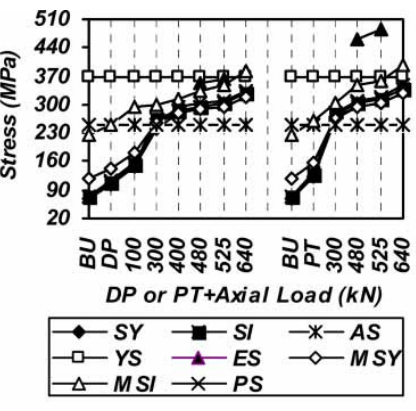

(b)

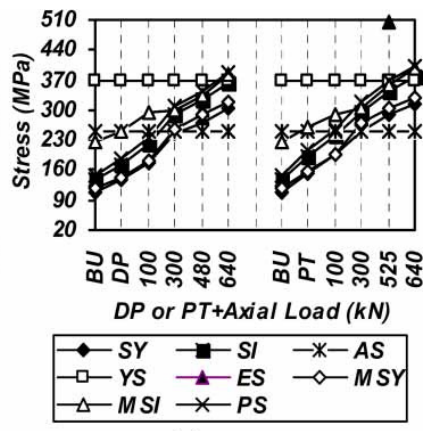

(c)

Fig. 2 SY and SI variation (FEA and experimental) at (a) pipe, (b) hub centre, and (c) hub flange fillet

\subsubsection{Stress intensity in flange}

At bolt-up plus internal pressure. Stresses (SY and SI) are measured numerically and experimentally at the hub centre (Fig. 2(b)) and hub flange fillet. The maximum SI observed at the hub-flange fillet at design pressure was close to the allowable stress and was slightly higher (261 MPa) at proof test pressure. However, the maximum stress intensity was much less than the yield stress of the flange material (Fig. 2(c)).

At design pressure plus axial loading. The maximum SI observed at the hub-flange fillet increased to $294 \mathrm{MPa}$ at design pressure and at an additional axial load of $100 \mathrm{kN}$. SI further increased linearly up to $381 \mathrm{MPa}$ at $640 \mathrm{kN}$ (Fig. 2(c)). Based on the design/failure criteria at allowable stress for optimized joint strength, the flange is safe at design pressure; hence the joint should be used up to the design pressure for some optimized additional axial loading.

At proof test pressure plus axial loading. The maximum SI at the hub-flange fillet increased to $291 \mathrm{MPa}$ at the proof test pressure and at an additional axial load of $100 \mathrm{kN}$. The SI further increased linearly to $396 \mathrm{MPa}$ at an axial load of $640 \mathrm{kN}$. Based on the design/failure criteria at the stress allowable for optimized joint strength, the flange was observed to be fail even at proof test pressure; hence, the joint should be used up to the design pressure for some optimized additional axial loading (Fig. 2(c)).

\subsubsection{Bending stress (SY)}

Two strain gauges were bonded at each location i.e. in the axial and hoop directions. Stresses calculated from experimental strains recorded at various strain-gauge locations during bolt-up and operating conditions were converted to principal stresses both in the axial and hoop directions using the expressions given in equations (1) and (2). FEA axial stresses are compared with the experimental stress results at strain-gauge locations.

$$
\begin{aligned}
& \sigma_{1}=\frac{E}{1-v^{2}}\left(\varepsilon_{1}+v \varepsilon_{2}\right) \\
& \sigma_{2}=\frac{E}{1-v^{2}}\left(\varepsilon_{2}+v \varepsilon_{1}\right)
\end{aligned}
$$

The FEA results under different conditions are given below. The experimental setup, procedure, and results are discussed in section 6 .

At bolt-up plus internal pressure. At bolt-up, the maximum SY of $117 \mathrm{MPa}$ increased to 144 and $158 \mathrm{MPa}$ at design and proof test pressure, respectively, and is observed to be within the allowable stress of the flange material (Figs 2(b) and (c) and 3(a) and 3(d)).

At design pressure plus axial loading. The maximum SY increased from $144 \mathrm{MPa}$ at design pressure to $183 \mathrm{MPa}$ and then almost linearly to $318 \mathrm{MPa}$ at $640 \mathrm{kN}$. The maximum SY exceeds the allowable stress limit at $300 \mathrm{kN}$ (Figs 2(b) and (c) and 3(b) and (c)).

At proof test pressure plus axial loading. The maximum SY increased from $158 \mathrm{MPa}$ at proof test pressure and then almost linearly to $331 \mathrm{MPa}$ at $640 \mathrm{kN}$. The maximum SY exceeded the allowable stress limit at $300 \mathrm{kN}$ (Figs 2(b) and (c) and 3(e) and (f)).

\subsubsection{Experimental versus FEA (design pressure plus axial loading)}

At hub centre. The principal experimental stresses, 352 and $365 \mathrm{MPa}$ at 480 and $525 \mathrm{kN}$, respectively, in addition to the design pressure were slightly more than the FEA principal stresses, 303 and $311 \mathrm{MPa}$, and axial stress, 289 and $296 \mathrm{MPa}$, respectively, close to the gauge location. This was due to the difference in the applied bolt-up, gauge location, and FEA measured results. The axial stress was found to be within the allowable stress up to $300 \mathrm{kN}$ and then exceeded at $400 \mathrm{kN}$, whereas principal stress exceeded allowable stress at $300 \mathrm{kN}$ (Fig. 2(b)) (Tables 3 and 4).

At hub-flange fillet. The principal experimental stress of $297 \mathrm{MPa}$ at $480 \mathrm{kN}$ in addition to the design pressure was less than the FEA principal stresses of 


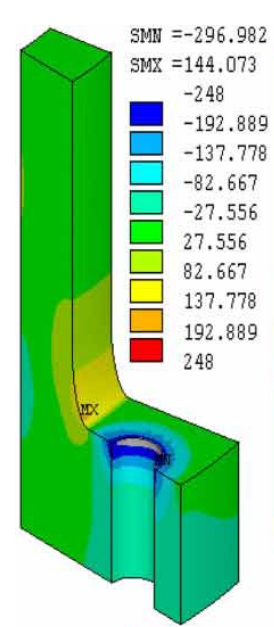

(a)

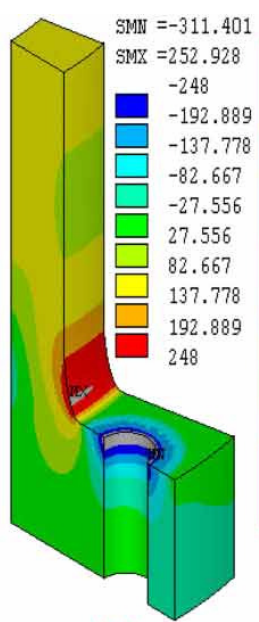

(b)

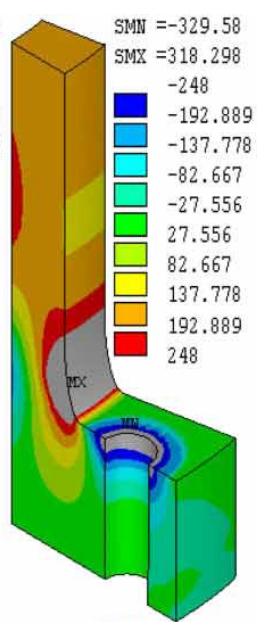

(c)

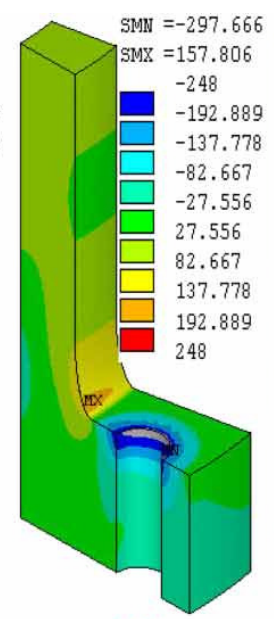

(d)

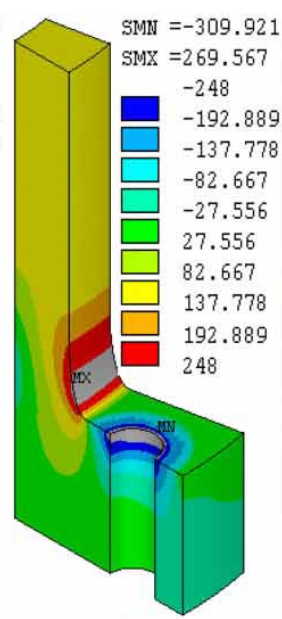

(e)

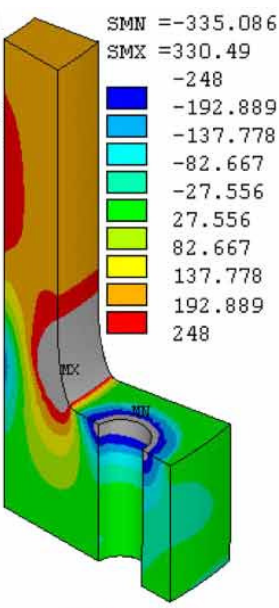

(f)

Fig. 3 SY in flange at (a) DP, (b) $\mathrm{DP}+300 \mathrm{kN}$, (c) $\mathrm{DP}+640 \mathrm{kN}$, (d) $\mathrm{PT}$, (e) $\mathrm{PT}+300 \mathrm{kN}$, and (f) PT+640 KN

Table 3 Stress variation (FEA and experimental) at hub centre at DP plus axial loading

\begin{tabular}{llllllllll}
\hline & BU & DP & $+100 \mathrm{kN}$ & $+200 \mathrm{kN}$ & $+300 \mathrm{kN}$ & $+400 \mathrm{kN}$ & $+480 \mathrm{kN}$ & $+525 \mathrm{kN}$ & $+640 \mathrm{kN}$ \\
\hline SY & 68.4 & 105 & 147 & 188 & 238 & 278 & 289 & 296 & 317 \\
SI & 71.9 & 109 & 152 & 194 & 264 & 287 & 297 & 304 & 327 \\
AS & 248 & 248 & 248 & 248 & 248 & 248 & 248 & 248 & 248 \\
YS & 370 & 370 & 370 & 370 & 370 & 370 & 370 & 370 & 370 \\
ES & & & & & & & 352 & 365 & \\
MSY & 117.2 & 144 & 183 & 216 & 253 & 279 & 289 & 296 & 318 \\
MSI & 226 & 249 & 294 & 290 & 298 & 316 & 334 & 347 & 381 \\
PS & 73.8 & 112 & 156 & 199 & 252 & 293 & 303 & 311 & 334 \\
\hline
\end{tabular}

Table 4 Stress variation (FEA and experimental) at hub centre at PT plus axial loading

\begin{tabular}{lrllllllll}
\hline & $\mathrm{BU}$ & $\mathrm{DP}$ & $+100 \mathrm{kN}$ & $+200 \mathrm{kN}$ & $+300 \mathrm{kN}$ & $+400 \mathrm{kN}$ & $+480 \mathrm{kN}$ & $+525 \mathrm{kN}$ & $+640 \mathrm{kN}$ \\
\hline SY & 68 & 123 & 166 & 211 & 265 & 283 & 295 & 304 & 330 \\
SI & 72 & 128 & 172 & 218 & 274 & 291 & 304 & 312 & 339 \\
AS & 248 & 248 & 248 & 248 & 248 & 248 & 248 & 248 & 248 \\
YS & 370 & 370 & 370 & 370 & 370 & 370 & 370 & 370 & 370 \\
ES & & & & & & & 461 & 487 & 304 \\
MSY & 117 & 158 & 197 & 232 & 270 & 283 & 296 & 331 \\
MSI & 226 & 261 & 291 & 292 & 306 & 326 & 346 & 359 & 396 \\
PS & 74 & 131 & 176 & 223 & 279 & 297 & 310 & 319 & 347 \\
\hline
\end{tabular}

$345 \mathrm{MPa}$ and greater than axial stress of $269 \mathrm{MPa}$ close to the gauge location. Axial stress was found to be within the allowable stress up to $300 \mathrm{kN}$, but exceeded at $400 \mathrm{kN}$, whereas the principal stress exceeded at about $120 \mathrm{kN}$ in addition to the design pressure (Fig. 2(c)) (Tables 5 and 6).

\subsubsection{Experimental versus FEA (proof test pressure plus axial loading)}

At hub centre. The principal experimental stresses, 462 and $487 \mathrm{MPa}$ at 480 and $525 \mathrm{kN}$, respectively, in addition to the proof test pressure were more than the FEA principal stresses 310 and $319 \mathrm{MPa}$, and axial stress.
295 and $306 \mathrm{MPa}$, respectively, close to the gauge location. These were due to the difference in pressure at bolt-up, larger gauge length, and some difference in gauge location and results measured by FEA. The axial stress was found within the allowable stress up to $300 \mathrm{kN}$ and then exceeded it at $400 \mathrm{kN}$, whereas principal stress exceeded allowed stress at $300 \mathrm{kN}$ (Fig. 2(b)) (Tables 3 and 4).

At hub-flange fillet. The principal experimental stresses, $506 \mathrm{MPa}$ at $525 \mathrm{kN}$, in addition to the proof test pressure was relatively more than the FEA principal stresses of $368 \mathrm{MPa}$ and axial stress (SY) of $287 \mathrm{MPa}$ close to the gauge location. These, it appeared, were due to the difference in bolt-up pressure, larger gauge length, and some difference in gauge location and 
Table 5 Stress variation (FEA and experimental) at hub-flange fillet at DP plus axial loading

\begin{tabular}{llllllllll}
\hline & BU & DP & $+100 \mathrm{kN}$ & $+200 \mathrm{kN}$ & $+300 \mathrm{kN}$ & $+400 \mathrm{kN}$ & $+480 \mathrm{kN}$ & $+525 \mathrm{kN}$ & $+640 \mathrm{kN}$ \\
\hline SY & 107 & 137 & 179 & 216 & 243 & 256 & 269 & 278 & 303 \\
SI & 139 & 173 & 223 & 267 & 289 & 306 & 322 & 333 & 363 \\
AS & 248 & 248 & 248 & 248 & 248 & 248 & 248 & 248 & 248 \\
YS & 370 & 370 & 370 & 370 & 370 & 370 & 370 & 370 & 370 \\
ES & & & & & & & 297 & & \\
MSY & 117 & 144 & 183 & 216 & 253 & 279 & 289 & 296 & 318 \\
MSI & 226 & 249 & 294 & 290 & 298 & 316 & 334 & 347 & 381 \\
PS & 149 & 185 & 238 & 284 & 311 & 327 & 345 & 356 & 389 \\
\hline
\end{tabular}

Table 6 Stress variation (FEA and experimental) at hub-flange fillet at PT plus axial loading

\begin{tabular}{llllllllll}
\hline & BU & DP & $+100 \mathrm{kN}$ & $+200 \mathrm{kN}$ & $+300 \mathrm{kN}$ & $+400 \mathrm{kN}$ & $+480 \mathrm{kN}$ & $+525 \mathrm{kN}$ & $+640 \mathrm{kN}$ \\
\hline SY & 107 & 153 & 195 & 227 & 249 & 263 & 278 & 287 & 315 \\
SI & 139 & 191 & 241 & 282 & 296 & 315 & 332 & 344 & 378 \\
AS & 248 & 248 & 248 & 248 & 248 & 248 & 248 & 248 & 248 \\
YS & 370 & 370 & 370 & 370 & 370 & 370 & 370 & 370 & 370 \\
ES & & & & & & & & 506 & \\
MSY & 117 & 158 & 197 & 232 & 270 & 283 & 296 & 304 & 331 \\
MSI & 226 & 261 & 291 & 292 & 306 & 326 & 346 & 359 & 396 \\
PS & 149 & 204 & 257 & 297 & 317 & 337 & 356 & 368 & 404 \\
\hline
\end{tabular}

FEA measured results. Axial stress was found to be within the allowable stress up to $300 \mathrm{kN}$, whereas principal stress exceeded allowed stress at about $100 \mathrm{kN}$ (Fig. 2(c)) (Tables 5 and 6).

From the preceding discussion, it can be concluded that the maximum SY at an axial load of $640 \mathrm{kN}$ was 318 and $303 \mathrm{MPa}$ at design pressure plus axial loading, and 331 and $315 \mathrm{MPa}$ at proof test pressure plus axial loading along the hub centre and hubflange fillet, respectively. The SY observed was less than the yield stress of the flange material. Similarly, the principal stress was 334 and $389 \mathrm{MPa}$ at design pressure plus axial loading, and 347 and $404 \mathrm{MPa}$ at proof test pressure plus axial loading at the hub centre and hub-flange fillet, respectively. Results shows that at $640 \mathrm{kN}$ the hub flange fillet yields. Based on the design/failure criteria at allowable stress for optimized joint strength, maximum axial load may be limited to 100 and $120 \mathrm{kN}$ at design pressure plus axial loading and proof test pressure plus axial loading, respectively. However, if the design/failure criteria are yield stress limits, then the maximum axial load applied can be up to about 600 and $580 \mathrm{kN}$ for the optimized performance at design pressure plus axial loading and at proof test pressure plus axial loading, respectively.

\subsubsection{FEA results of contact stress (SY) at bolt hole}

A good full-face contact was observed between the top surface of the flange under the bolt head. At bolt-up, the SY observed was of $299 \mathrm{MPa}$. Similarly, contact stress observed during internal pressures was 297 and $298 \mathrm{MPa}$ at design and proof test pressure, respectively. At combined design pressure and additional axial loading of $100-640 \mathrm{kN}$, it increased from 303 to $330 \mathrm{MPa}$. At combined proof test pressure and additional axial loading of $100-640 \mathrm{kN}$, it increased from 303 to $335 \mathrm{MPa}$. SY found even at bolt-up was higher than allowable stress. However, this localized stress should not be considered as flange failure, as the flange ring has a reasonable thickness. In fact, these stresses arise from the high initial preload applied in the bolts and are always recommended for the non-gasketed joints (Fig. 3(a) to (f)).

\subsection{Stress variation in bolts}

\subsubsection{FEA results of stress intensity (SI)}

At bolt-up plus internal pressure. The maximum SI of $725 \mathrm{MPa}$ during bolt-up, remained unchanged at design pressure, but increased slightly to $730 \mathrm{MPa}$ under proof test pressure. Close to the gauge location, SI at the inside and outside nodes was 474 and $440 \mathrm{MPa}$, respectively, at bolt-up. It increased to 480 and $486 \mathrm{MPa}$ at the inside node and 438 and $474 \mathrm{MPa}$ at the outside node at design and proof test pressure, respectively (Fig. 4(a))

At design pressure plus axial loading. The maximum SI increased linearly from 736 to $791 \mathrm{MPa}$ at an additional axial load of $100-640 \mathrm{kN}$. The maximum SI remained linear than the allowable stress limit at all loading conditions. Close to the gauge location, SI at the inside and outside nodes increased from 498 to $647 \mathrm{MPa}$ and 447-570 MPa at an additional axial load of $100-640 \mathrm{kN}$. SI reached the allowable stress limit at an 


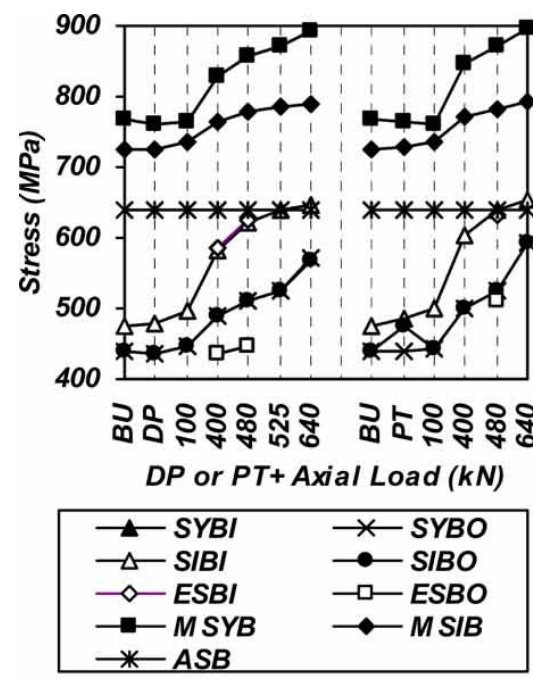

(a)
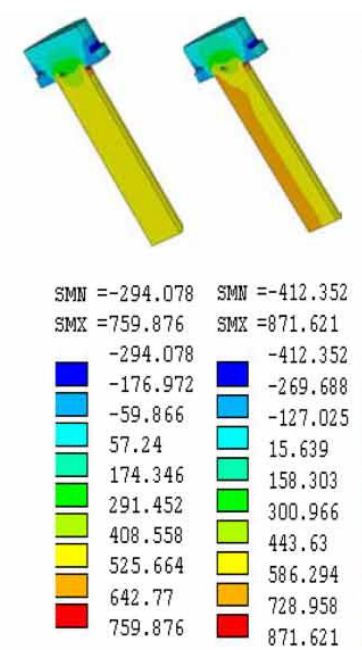

(b)

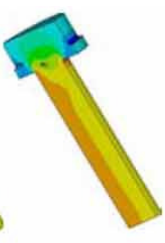

(c)

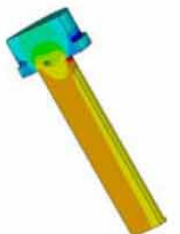

SMN $=-440.882$ SMX $=893.48$

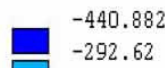

$\square$

$\square \quad 152.1$

300.43

448.692

596.955

745.217

893.48

(d)
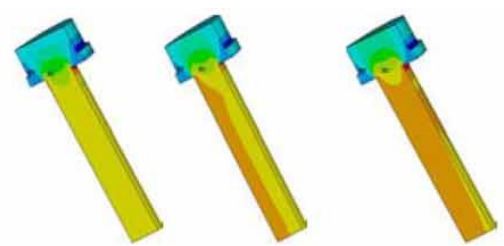

SMN $=-297.916 \quad$ SMN $=-412.87^{\circ}$ SMN $=-446.16$ SMX $=766.404 \quad$ SMX $=871.992 \quad$ SMX $=897.534$

$-297.916-412.87-446.16$

-179.658
-61.401

56.857

175.115

293.373

411.631

529.888

648.146

766.404

(e)

(f)

Fig. 4 (a) Stress variation at DP and PT and axial loading at gauge location; FEA versus experimental results, axial stress in bolt at (b) DP, (c) DP $+525 \mathrm{kN}$, (d) DP $+640 \mathrm{kN}$, (e) PT, (f) PT +480 , and (g) PT+640

axial load of $525 \mathrm{kN}$ in addition to the design pressure (Fig. 4(a)).

At proof test pressure plus axial loading. The maximum SI increased linearly from $736 \mathrm{MPa}$ to $792 \mathrm{MPa}$ at an additional axial load of $100-640 \mathrm{kN}$. Maximum SI remained more than the allowable stress limit at all loading conditions. Close to the gauge location, SI at inside and outside nodes increased from $500 \mathrm{MPa}$ to $652 \mathrm{MPa}$ and $444 \mathrm{MPa}-594 \mathrm{MPa}$ at an additional axial load of $100-640 \mathrm{kN}$. SI $(641 \mathrm{MPa})$ exceeded the allowable stress limit at an axial load of $480 \mathrm{kN}$ in addition to the proof test pressure (Fig. 4(a)).

\subsubsection{FEA results of axial stress (SY)}

At bolt-up plus internal pressure. The maximum SY of $769 \mathrm{MPa}$ at bolt-up decreased to 760 and $766 \mathrm{MPa}$ at design and proof test pressure, respectively, and were observed to be higher than the allowable stress limit. Close to the gauge location, SY at the inside and outside nodes was $474 \mathrm{MPa}$ and $440 \mathrm{MPa}$, respectively, at bolt-up, which increased linearly from 480 to 485 and 437-438 MPa at design and proof test pressure, respectively. The SY observed was within the allowable stress limit up to the proof test pressure at gauge location (Figs 4(a), (b), and (e)). At bolt-bottom (L-6), an SY of $467 \mathrm{MPa}$ at bolt-up increased to 475 and $481 \mathrm{MPa}$ at design and proof test pressure, respectively, at the inside node of the bolt. The SY of $425 \mathrm{MPa}$ at bolt-up decreased to $420 \mathrm{MPa}$ at design and proof test pressure at the outside node of the bolt. However, SY remained within the allowable stress limit at both pressures at bolt-bottom (Fig. 5(a)). The average bolt stress of $457 \mathrm{MPa}$ at bolt-up increased to 458 and $461 \mathrm{MPa}$ at design and proof test pressures, respectively and was less than 1 per cent, showing a static mode of load of non-gasketed joint.

At design pressure plus axial loading. The maximum SY increased linearly from $763 \mathrm{MPa}$ to $893 \mathrm{MPa}$ at an additional axial load of $100-640 \mathrm{kN}$. The maximum SI remained higher than the allowable stress limit at all loads. Close to the gauge location, SY at the inside and outside nodes increased from 498 to $647 \mathrm{MPa}$ and 447-570 MPa, respectively, at an additional axial load of $100-640 \mathrm{kN}$. SY reached the allowable stress limit at an axial load of $525 \mathrm{kN}$ in addition to the design pressure (Figs 4(a), (c), and (d)). At bolt-bottom (L-6), the SY of $475 \mathrm{MPa}$ at design pressure increased to $494-$ $654 \mathrm{MPa}$ at the inside node, and the SY of $420 \mathrm{MPa}$ at proof test pressure increased to $429-512 \mathrm{MPa}$ at the outside node of the bolt at an axial load of 100-640 kN. The SY at bolt-bottom reached the allowable stress limit at $525 \mathrm{kN}$ (Fig. 5(a)). The average bolt stress of $448 \mathrm{MPa}$ at design pressure increased to $462-583 \mathrm{MPa}$ (4-31 per cent) at an additional axial load from 100 to $640 \mathrm{kN}$ at bolt-bottom and gauge location. Results showed that bolt-bending increases with an increase in axial loading.

At proof test pressure plus axial loading. The maximum SY increased linearly from 761 to $898 \mathrm{MPa}$ at an additional axial load of $100-640 \mathrm{kN}$. The maximum SI remained more than the allowable stress limit at all loads. Close to the gauge location, SY at the inside and outside nodes increased from 500 to $652 \mathrm{MPa}$ and 444$594 \mathrm{MPa}$ at an additional axial load of $100-640 \mathrm{kN}$. The SY reached the allowable stress limit at an axial load of $480 \mathrm{kN}$, in addition to the proof test pressure (Figs 4(a), 


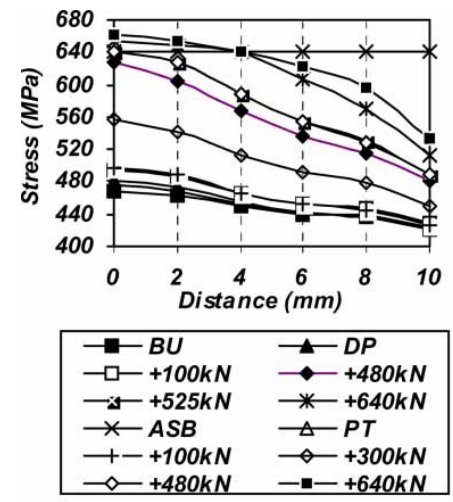

(a)

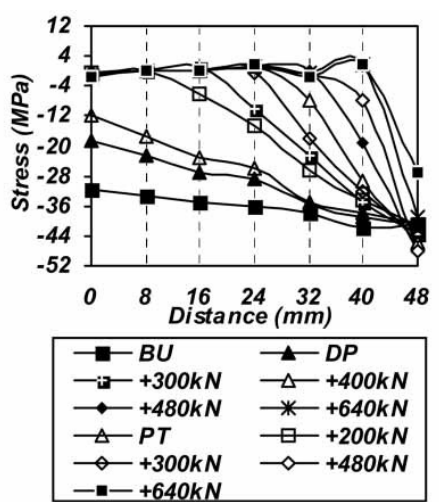

(b)

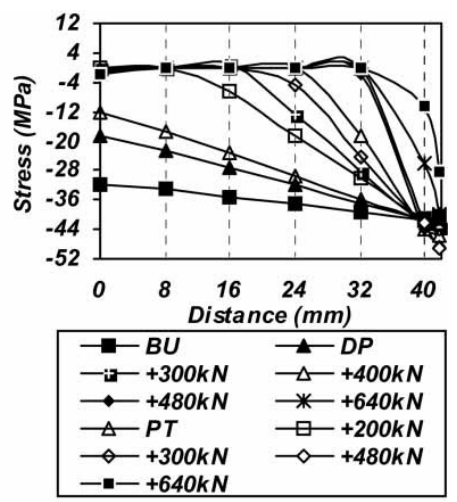

(c)

Fig. 5 (a) Stress variation at DP and PT and axial loading at bolt bottom: SY variation for DP and PT in symmetry plate, (b) along bolt holes, and (c) between bolt holes

(f), and (g)). At bolt-bottom (L-6), SY of 481 and $420 \mathrm{MPa}$ at the inside and outside nodes of the bolt at proof test pressure increased from 497 to $661 \mathrm{MPa}$ and 425-533 MPa, respectively, at an additional axial load from 100 to $640 \mathrm{kN}$. The SY at bolt-bottom reached the allowable stress limit at $480 \mathrm{kN}$ (Fig. 5(a)). An average bolt stress of $451 \mathrm{MPa}$ at proof test pressure increased to $461-597 \mathrm{MPa}$ (3-34 per cent) at an additional axial load from 100 to $640 \mathrm{kN}$. Results showed bolt-bending increases with the increase of axial loading.

\subsubsection{Experimental versus FEA}

At design pressure plus axial loading. The SY calculated experimentally, $587 \mathrm{MPa}$ at $400 \mathrm{kN}$ and $626 \mathrm{MPa}$ at $480 \mathrm{kN}$ were close to the FEA results, $581 \mathrm{MPa}$ at $400 \mathrm{kN}$ and $621 \mathrm{MPa}$ at $480 \mathrm{kN}$ at the inside node. The SY calculated experimentally, $437 \mathrm{MPa}$ at $400 \mathrm{kN}$ and $448 \mathrm{MPa}$ at $480 \mathrm{kN}$ were close to the FEA results of $491 \mathrm{MPa}$ at $400 \mathrm{kN}$ and $512 \mathrm{MPa}$ at $480 \mathrm{kN}$ at the outside node. Results show that SY at the gauge location reached allowable stress limit at $525 \mathrm{kN}$ (Fig. 4(a)).

At proof test pressure plus axial loading. The SY calculated experimentally, 632 and $510 \mathrm{MPa}$ at the inside and outside nodes were close to the FEA results, 640 and $526 \mathrm{MPa}$ at the inside and outside nodes, respectively, at $480 \mathrm{kN}$. Results show that SY at the gauge location reached the allowable stress limit at $480 \mathrm{kN}$ (Fig. 4(a)).

\subsection{Contact stresses variation between flange faces - FEA results}

At bolt-up plus internal pressure. At the inside diameter of a symmetry plate, along bolt hole (L-4) and between bolt holes (L-5), a contact stress of - $32 \mathrm{MPa}$ at bolt-up at the inside diameter decreased to -19 MPa at design pressure and $-12 \mathrm{MPa}$ at proof test pressure. Along L-4 and L-5 at design and proof test pressures, a good contact stress was found along, concluding no chances of leakage from the joint (Figs 5(b) and (c) and 6(a) and (d)).

At design pressure plus axial loading. At the inside diameter of a symmetry plate along bolt hole (L-4) and between bolt holes (L-5), a contact stress of $-19 \mathrm{MPa}$ at design pressure at the inside diameter decreased to $-7 \mathrm{MPa}$ at an additional axial load of $100 \mathrm{kN}$. Contact stress further decreased rapidly to $-0.2 \mathrm{MPa}$ at $200 \mathrm{kN},-0.4 \mathrm{MPa}$ at $300 \mathrm{kN},-0.8 \mathrm{MPa}$ at $400 \mathrm{kN}$. It then increased to $-1 \mathrm{MPa}$ at $480-640 \mathrm{kN}$. Along L-4 and L-5, during bolt-up, design pressure and axial load up to $100 \mathrm{kN}$, a good contact stress was found. Contact start after $4.12 \mathrm{~mm}$ at $200 \mathrm{kN}, 13.7 \mathrm{~mm}$ at $300 \mathrm{kN}, 26.7 \mathrm{~mm}$ at $400 \mathrm{kN}, 26.95 \mathrm{~mm}$ at $480 \mathrm{kN}, 27 \mathrm{~mm}$ at 525 and $640 \mathrm{kN}$ along L-4. Contact stress found along L-5 had similar behaviour as L-4 except for $480 \mathrm{kN}$, where contact starts after $31.6 \mathrm{~mm}, 32 \mathrm{~mm}$ for $525 \mathrm{kN}$, and $34.3 \mathrm{~mm}$ for $640 \mathrm{kN}$ (Figs 5(b) and (c) and 6(b) and (c)).

At proof test pressure plus axial loading. At the inside diameter of a symmetry plate along bolt hole (L-4) and between bolt holes (L-5), contact stress of $-12 \mathrm{MPa}$ at proof test pressure at the inside diameter decreased to $-1 \mathrm{MPa}$ at an additional axial load of $100 \mathrm{kN}$. Contact stress further decreased rapidly to $-0.3 \mathrm{MPa}$ at $200 \mathrm{kN},-0.6 \mathrm{MPa}$ at $300 \mathrm{kN}$. It then increased to $-1 \mathrm{MPa}$ at $400-640 \mathrm{kN}$. Along L-4 and L-5, during bolt-up, proof test pressure and an axial load up to $100 \mathrm{kN}$, a good contact stress found. Contact start after $11.8 \mathrm{~mm}$ at $200 \mathrm{kN}, 22.6 \mathrm{~mm}$ at $300 \mathrm{kN}$, $26.85 \mathrm{~mm}$ at $400 \mathrm{kN}, 26.95 \mathrm{~mm}$ at $480 \mathrm{kN}, 27 \mathrm{~mm}$ at $525 \mathrm{kN}$, and $640 \mathrm{kN}$ along L-4. Contact stress found along L-5 had similar behaviour as L-4 except for $480 \mathrm{kN}$, where contact starts after $29.1 \mathrm{~mm}, 32.7 \mathrm{~mm}$ for $525 \mathrm{kN}$ and $37 \mathrm{~mm}$ for $640 \mathrm{kN}$ (Figs 5(b) and (c) and $6(\mathrm{e})$ and (f)).

Summarizing the above, even though contact is reduced with an increase in the axial load, however, 

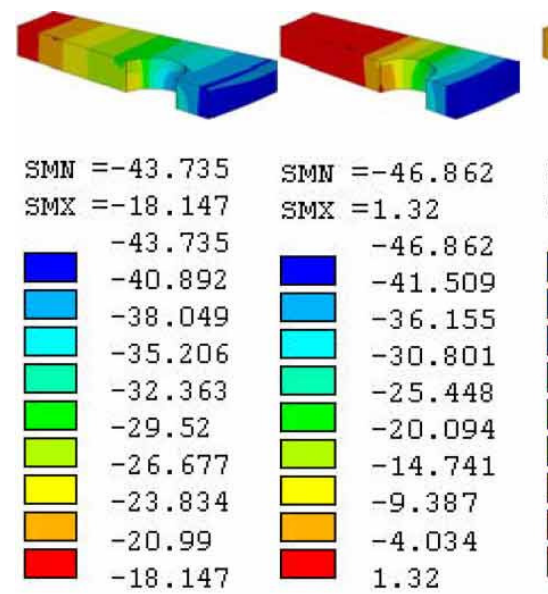

(a)

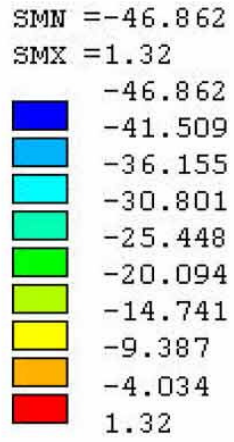

(b)

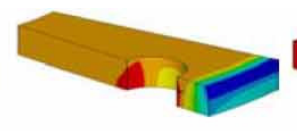

SMN $=-40.131$

SMX $=8.372$

$-40.131$

$-34.741$

$-29.352$

$-23.963$

$-18.574$

$-13.185$

$-7.795$

$-2.406$

2.983

8.372

(c)

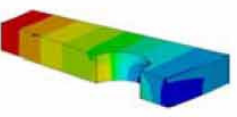

SMN $=-45.141$

$\operatorname{SMX}=-11.413$

$-45.141$

$-41.394$

$-37.646$

$-33.899$

$-30.151$

$-26.403$

$-22.656$

$-18.908$

$-15.161$

$-11.413$

(d)

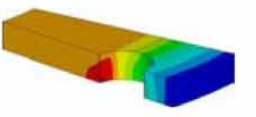

SMN $=-49.17$

SMX $=8.121$

$-49.17$

$-42.805$

$-36.439$

$-30.073$

$-23.707$

$-17.342$

$-10.976$

$-4.61$

1. 755

8.121

(e)

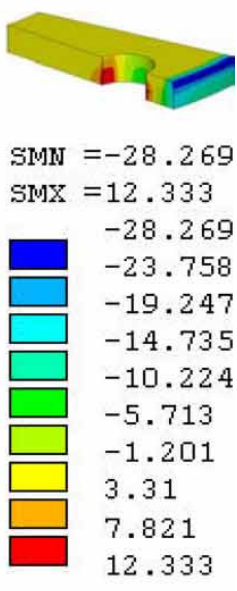

(f)

Fig. 6 Contact stress (SY) at (a) DP, (b) DP+300 kN, (c) DP+640 kN, (d) PT, (e) PT $+300 \mathrm{kN}$, and (f) $\mathrm{PT}+640 \mathrm{kN}$

proper contact at the inside diameter is due to the positive taper angle at the flange surface, even up to an axial load of $640 \mathrm{kN}$. Similarly, reduced contact is observed along L4 and L5. As the bolt inside diameter along L4 is measured at a distance of $24.25 \mathrm{~mm}$ and this is the shortest path for the leakage; hence this shows that at any load more than $350 \mathrm{kN}$ (for design pressure plus axial loading) and $300 \mathrm{kN}$ (for proof test pressure plus axial loading) there is no possibility of leakage from the bolt holes and between bolt holes.

\subsection{Axial displacement - FEA results only}

At bolt-up plus internal pressure. At the inside diameter of the flange (L-1), an axial nodal displacement of $-0.0175 \mathrm{~mm}$ at bolt-up, increased to $-0.0112 \mathrm{~mm}$ and $-0.0737 \mathrm{~mm}$ at design and proof test pressure at the inside diameter. In addition, no positive axial displacement along L4 and L5 shows a good sealing;

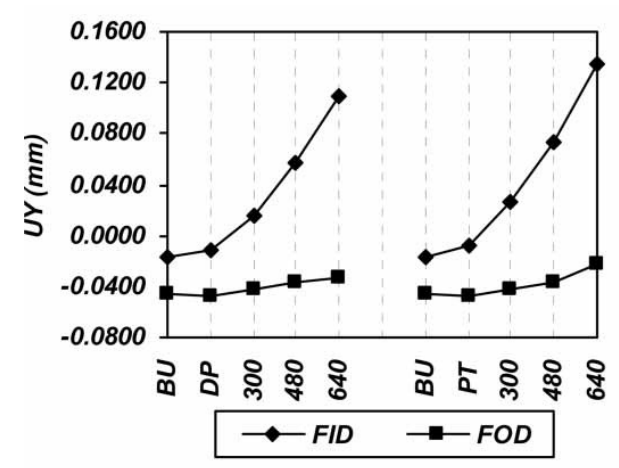

(a) hence providing no chance of leakage up to proof test pressure (Figs 7(a) and (b)).

At design pressure plus axial loading. At the inside diameter of the flange (L1), an axial nodal displacement of $0.0112 \mathrm{~mm}$ at design pressure increased to $-0.0368 \mathrm{~mm}$ at $100 \mathrm{kN}$. It increased to $0.00377 \mathrm{~mm}$ at $200 \mathrm{kN}, 0.0162 \mathrm{~mm}$ at $300 \mathrm{kN}, 0.0368 \mathrm{~mm}$ at $400 \mathrm{kN}$, $0.0574 \mathrm{~mm}$ at $480 \mathrm{kN}, 0.0706 \mathrm{~mm}$ at $525 \mathrm{kN}$, and $0.11 \mathrm{~mm}$ at $640 \mathrm{kN}$. Along L4 and L5 a good sealing has been observed up to an additional axial load of $100 \mathrm{kN}$. Axial flange displacement along L4 and L5 beyond $3.23 \mathrm{~mm}$ at $200 \mathrm{kN}, 11.1 \mathrm{~mm}$ at $300 \mathrm{kN}, 19.4 \mathrm{~mm}$ at $400 \mathrm{kN}, 27.3 \mathrm{~mm}$ at $480 \mathrm{kN}, 30.3 \mathrm{~mm}$ at $525 \mathrm{kN}$, and $35 \mathrm{~mm}$ at $640 \mathrm{kN}$ in addition to the design pressure (Figs 7 (a) and (b)).

At proof test pressure plus axial loading. At the inside diameter of flange (L1), axial nodal displacement $-0.0737 \mathrm{~mm}$ at proof test pressure increased to $-0.00055 \mathrm{~mm}$ at $100 \mathrm{kN}$. It increased to $0.00949 \mathrm{~mm}$

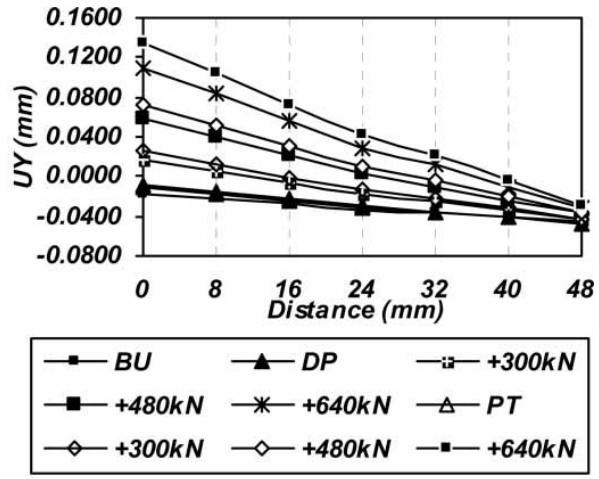

(b)

Fig. 7 Axial flange displacement for DP and PT plus axial loading (100-640 kN) at (a) inside and outside diameters and (b) along bolt holes 
at $200 \mathrm{kN}, 0.0263 \mathrm{~mm}$ at $300 \mathrm{kN}, 0.0505 \mathrm{~mm}$ at $400 \mathrm{kN}$, $0.073 \mathrm{~mm}$ at $480 \mathrm{kN}, 0.0872 \mathrm{~mm}$ at $525 \mathrm{kN}$, and $0.135 \mathrm{~mm}$ at $640 \mathrm{kN}$. Along L4 and L5, a good sealing has been observed up to an additional axial load of $100 \mathrm{kN}$. Axial flange displacement along L4 and L5 beyond $7 \mathrm{~mm}$ at $200 \mathrm{kN}, 15.4 \mathrm{~mm}$ at $300 \mathrm{kN}, 23 \mathrm{~mm}$ at $400 \mathrm{kN}, 30.4 \mathrm{~mm}$ at $480 \mathrm{kN}, 32.4 \mathrm{~mm}$ at $525 \mathrm{kN}$, and $37.4 \mathrm{~mm}$ at $640 \mathrm{kN}$ in addition to the proof test pressure (Figs 7(a) and (b)).

Summarizing the above, axial flange displacement at the inside diameter at $200 \mathrm{kN}$ and above is more than zero mm, although it is very small. As Compared to the contact stress of $-1 \mathrm{MPa}$ up to $664 \mathrm{kN}$ at the inside diameter it seems to be almost negligible and it appears to be due to the positive taper angle at the flange surface. As the bolt's inside diameter along L4 and L5 is measured at a distance of $24.25 \mathrm{~mm}$, and this is the shortest path for the leakage; at any load more than 450 and $410 \mathrm{kN}$ at design and proof test pressure plus axial loading, respectively, and there could be leakage from the bolt holes (Figs 7(a) and (b)). From these results, it appears that the application of externally applied axial loadings, in addition to the internal pressure applied, has a pronounced effect on the axial displacement and consequently on the sealing of the joint, as it increases with an increase in axial loadings, thereby allowing the possibility of leakage.

\section{EXPERIMENTAL PROGRAMME}

\subsection{Flange type, size, tools, and test rig component selection}

A non-gasketed flange joint equivalent to 4 in, class 900\# joint size were selected and an appropriate test rig made. This size is commonly used in the industrial sector, and is easy to handle in the laboratory, and all tooling required are easily available. For all series of tests, non-gasketed flanges with and without O-rings and the tools used to make then joint assembly are shown in Figs 8(a) to (c). Flanges and pipe are arranged recommended by codes and the industrial sector. End caps at the end of the pipe pieces are designed as per
PD5500 [18] and the remaining calculations for the saddle, frame, pin and side-bars are based on a general structure design [4].

\subsection{Strain gauging and instrumentation}

To measure the strength of the test rig comprising flanges, pipes, bolts, and supporting structure, strain gauges were placed at different major locations. The data logging system was connected to the test rig record results from strain gauges attached at the bolts, frame, flange, pipe section, pressure transducer, and test machine.

Bolts. Two strain gauges of $350 \mathrm{ohm}$ were placed on the shanks at an angle of $180^{\circ}$ on each bolt and leads were taken out between the washer and bolt head, as shown in Fig. 9(a). Quarter and full bridge circuit were used for strain measurements.

Side frame. For tests, axial load was applied using a hydraulic pump and readings taken from the pressure gauge attached to the pump. To accurately measure the digital or electronic data during the application of different loads, it was decided to attach two pairs of strain gauges of $120 \mathrm{ohm}$ on the frame (free end) side plates that hold the pin (Fig. 9(b)). The side frame was calibrated before using in actual tests, and applied load was calculated from the strain recorded.

Flange and pipe. Four pairs of strain gauges of $120 \mathrm{ohm}$ resistance were attached to hub centre and at hub-flange locations at an angle of $90^{\circ}$. At the hubflange, the intersection strain gauges were attached at the fillet as well as along the elliptical portion to accurately record stress behaviour. Four pairs of strain gauges of $120 \mathrm{ohm}$ were attached at an angle of $90^{\circ}$ at the pipe centre away from the locations of discontinuity (Fig. 9(c)).

\subsection{Calibration of bolts and rig and test rig assembly}

Calibration plays an important role when undertaking experimental work, so as to avoid any possibility of unknown errors in strain measurements. To identify

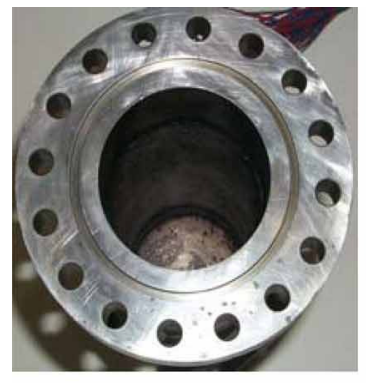

(a)

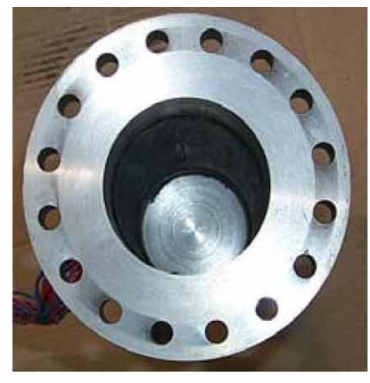

(b)

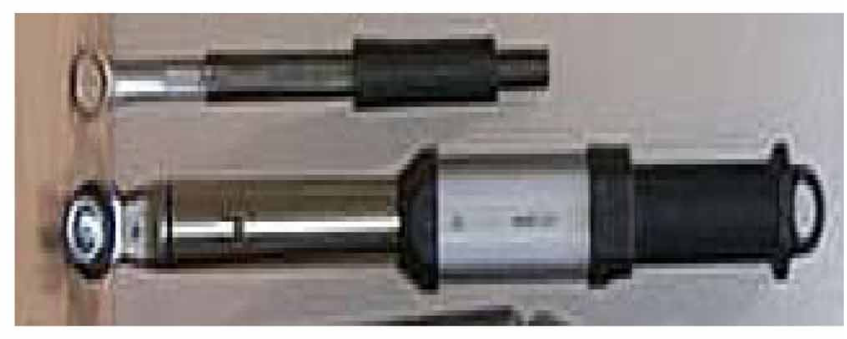

(c)

Fig. 8 Non-gasketed flanges: (a) without O-ring groove, (b) with O-ring groove, and (c) tools used for joint assembly 


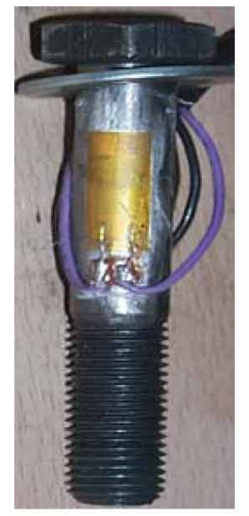

(a)

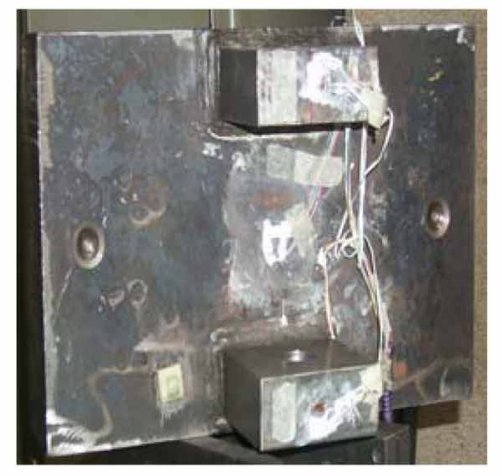

(b)

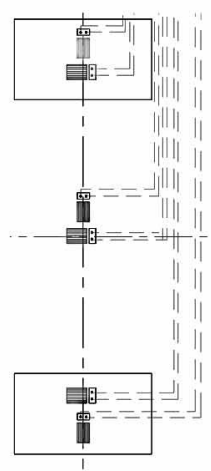

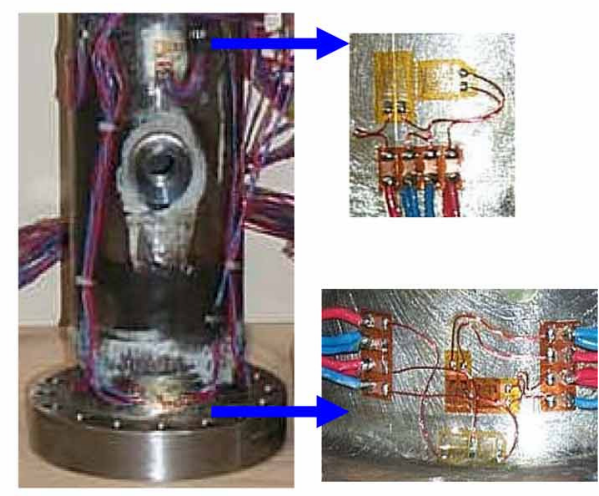

(c)

Fig. 9 Strain gauging of (a) bolt, (b) side frame, and (c) pipe and flange section

these interactions, before actual experiments, calibration of different joint components is performed. During experiments for combined loading a combination of equipment was used: bolts, pressure gauges, pressure transducer, hydraulic pumps, hydraulic pistons, machine for bending load, side frame for axial load, and clip gauge for joint opening measurement. Using an 'hand-tightening' methodology with ordinary spanner, 16 bolts were normally tightened as in the following sequence: i.e. $1,9,5,13,3,11,7,15,2,10$, $6,14,4,12,8$, and 16 [4].

\subsection{At internal pressure only}

Internal pressure loading is currently the prime method of loading as per available codes and standards as flanged pipe joints are designed to withstand this. Pressure loading is applied to the assembled joint via a manually operated hand pump of $50 \mathrm{MPa}$ (500 bar) capacity. Pressure gauges on the pump and a pressure transducer on the test vessel are attached to record fluid pressure. Internal pressure loading up to a design pressure of 15.3 MPa, proof test pressure of $23 \mathrm{MPa}$, and maximum pressure of $40 \mathrm{MPa}$ at unloading was applied in gradual increments and decrements of $0.5 \mathrm{MPa}$ ( 5 bar). The test rig arrangement is shown with sudden pressurization and depressurization. Results were recorded in Fig. 10(a).

\subsection{At combined internal pressure and axial loading}

After filling the test rig with hydraulic fluid, axial load was applied via two symmetric parallel shafts loaded by hydraulic cylinders (Fig. 10(b)). This tensile load was transferred to the pipe by the heavy end plates and a pin-type connector, which was located between the assembly and the loaded shafts. The end plates were designed such that they were rigid enough to transfer the load from the shafts to the pipe assembly. The maximum axial force applied was based on the preload applied in bolts [4] i.e. $480 \mathrm{kN}$ was applied based on recommended torque in bolts. Axial force was applied equal to and more than the calculated

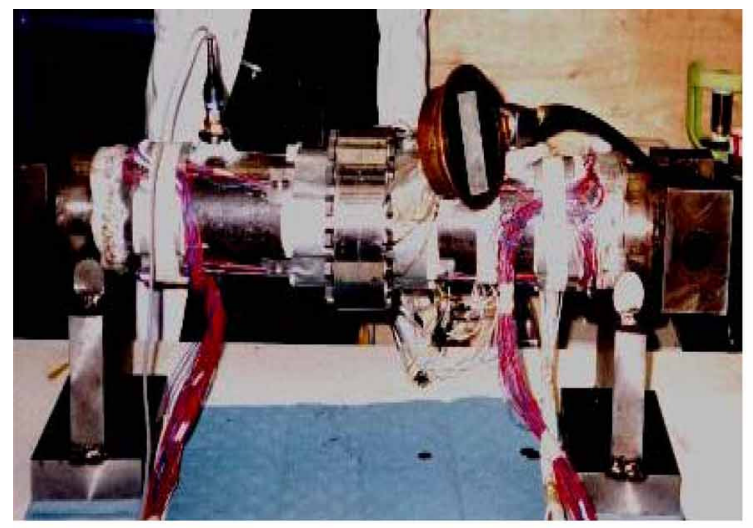

(a)

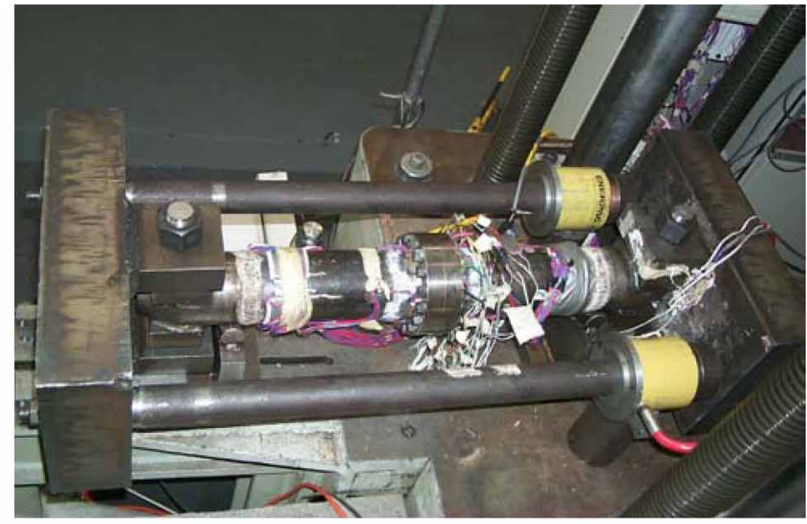

(b)

Fig. 10 Arrangement for (a) internal pressure loading and (b) internal pressure plus axial loading 
force $(480,525$, and $664 \mathrm{kN})$ to see the effect on bolt strain. The load was not applied beyond these maximum values to avoid the pipe and flange yielding, as well as due to the limitation of the hydraulic pump available. The side frame was designed and calibrated for a maximum axial load of $700 \mathrm{kN}$. Tests were performed varying the axial load with internal pressure of 15.3 and $23 \mathrm{MPa}$ (153 and $230 \mathrm{bar}$ ), respectively, for loads and in increments of $0.5 \mathrm{MPa}$ (5 bar) at the start and then at about $0.2-0.4 \mathrm{MPa}(20-40 \mathrm{bar})$. Axial load was applied in increments of about $200 \mathrm{psi}$ at the start and then increased to $300-400 \mathrm{psi}$.

\subsection{Experimental results discussion and conclusions}

The joint assembly without the O-ring was tested at a maximum axial load of $525 \mathrm{kN}$, which was more than the applied pre-load of $480 \mathrm{kN}$ in the bolts of the joint. No leakage was observed. The joint assembly with the O-ring was tested for two sets of tests with load variation of up to a maximum axial load of $664 \mathrm{kN}$ (10 per cent more than the load of $594 \mathrm{kN}$ to cause yielding of the bolts). This calculated load was based on the root area $\left(58 \mathrm{~mm}^{2}\right)$ of the bolt. The first set of tests was completed with a maximum axial load of up to $525 \mathrm{kN}$, and no leakage was observed. This shows the sealing capability of the non-gasketed joint without the O-ring. The second test was performed for a maximum load of $664 \mathrm{kN}$. At this load, a small opening at the bottom of the joint was observed. Two bolts at the bottom were found to have relaxed and they were re-tightened. The test rig was pressurised for the combined load test. A rapid increase in bolt strain was noted at pressure loads lower than the maximum permissible working pressure. However, it is important to note that no leakage was observed from the joint. All the bolts were then checked and a very small elongation in 12 bolts was noted, which was not visible and was felt only by matching the threads with the threads of the virgin or original bolt. However, the leak proof behaviour was also noted during the internal pressure loading. No leakage was observed from the joint assemblies with the O-ring, proving it was leak proof. Even at the load of $664 \mathrm{kN}$, when the bolts had elongated and an opening was observed in the joint at the bottom, no fluid seepage or leakage was observed from the joint. This shows the sealing capability of the joint.

From the overall strain behaviours all sections of flange and pipe, the material behaviour is almost linear elastic during loading and unloading. However, the possibility of other factors such as deformation produced during welding, dimensional variation during manufacturing, and a slight variation in the location of the gauges cannot be ruled out. For the bolts, the stress result variation is due to the difference in bolt quality and surface treatment, affecting the pre-load applied in the bolts.

\section{CONCLUSIONS}

From the results, at bolt-up and up to proof test pressure loading, the almost static-mode-of-load has shown the non-gasketed flange joint's strength and sealing capability, both experimentally and numerically. However, at additional axial loading, joint performance is affected. This highlights the importance of determining the actual joint load capacity for the optimized joint strength and sealing capability, showing that any joint designed for only internal pressure may fail under any external axial loading. During the present study, from the detailed experimental and numerical studies, a maximum upper limit with applied design and proof test pressure has been determined and is recommended for an optimized performance. In this study, a bolt-up of 74 per cent of the yield stress of the bolt material was applied, which resulted in greater stress variation in bolt and flange. However, a minimum initial bolt-up load of 80 per cent of the yield stress of the bolt material is essential for proper joint sealing under combined internal pressure and axial loading. Summarizing based on the static mode-of-load in the joint, both qualitatively and quantitatively, a non-gasketed flange joint with a positive taper angle can be used for any additional axial loading for safe strength and sealing.

\section{ACKNOWLEDGEMENT}

The authors are grateful to Department of Mechanical Engineering, University of Strathclyde, Glasgow, UK, for providing a test rig for experimental work and the Pakistan Science Foundation, Islamabad, for providing funding to carry out this study.

\section{REFERENCES}

1 BS 1560:1989. Steel pipe flanges for the petroleum industry. British Standards Institution, London, UK.

2 ASME boiler and pressure vessel code, section VIII, 1998 (American Society of Mechanical Engineers, New York, USA).

3 Abid, M. and Nash, D. H. Comparative study of the behaviour of conventional gasketed and compact nongasketed flanged pipe joints under bolt up and operating conditions. Int. J. Press. Vessels Pip., 2004, 80, 831-841.

4 Abid, M. Experimental and Analytical studies of conventional (gasketed) and unconventional (non gasketed) flanged pipe joints (with special emphasis on the engineering of 'joint strength' and 'sealing'). PhD Thesis, 2000 . 
5 Webjörn, J. Flange design in Sweden. In the Petrochemical Mechanical Engineering Conference, American Society of Mechanical Engineers, Philadelphia, USA, 1967, pp. 17-20.

6 Webjörn, J. The bolted joint - a series of problems. Linköping Studies in Science and Technology, Dissertation No. 130, 1985.

7 Abid, M., Nash, D. H., and Webjörn, J. The stamina of non-gasketed flanges. In the International Conference on Fatigue 2000, Cambridge, UK, pp. 575-584.

8 Abid, M. and Nash, D. H. A parametric study of metal-tometal contact flanges with optimised geometry for safe stress and no-leak conditions. Int. J. Press. Vessels Pip., 2004, 81, 67-74.

9 Abid, M. Determination of safe operating conditions for non-gasketed flange joint under combined internal pressure and temperature. Int. J. Mech. Mater. Des., 2005, 2, 129-140.

10 Abid, M. Design and analysis of non-gasketed bolted flanged pipe joint under combined internal pressure and temperature loading. In the 3rd BSME-ASME International Conference on Thermal Engineering, Dhaka, Bangladesh, 20-22 December 2006.

11 Morohoshi, T. and Sawa, T. On the characteristics of rectangular bolted flanged connections with gaskets subjected to external tensile loads and bending moments. $J$. Press. Vessel Technol. Trans. ASME, 1994, 116(2), 207-215.

12 Fukuoka, T. and Takaki, T. Three dimensional finite element analysis of pipe flange - effect of flange interface geometry. ASME Press. Vessel Piping, 1998, 367, 61-67.

13 ASME boiler and pressure vessel code, section II, part D, 1998 (American Society of Mechanical Engineers, New York, USA).

14 BS 3692:1967. Specifications for ISO metric precision hexagonal bolts, screws and nuts. British Standards Institution (BSI), London, UK.

15 Spence, J., Macfarlane, D. M., and Tooth, A. S. Metal-tometal full face taper hub flanges: finite-element model evaluation and preliminary plastic analysis. Proc. Instn Mech. Engrs, Part E: J. Process Mechanical Engineering, 1998, 212(E), 57-69.

16 ANSYS elements manual, seventh edition, 2004 (ANSYS Inc., USA).

17 Spence, J. and Tooth, A. S. Pressure vessel design concepts and principles, 1994 (E \& FN Spon, London, New York).

18 PD 5500:1997. Unfired fusion welded pressure vessels, British Standards Institution (BSI), London, UK.

\section{APPENDIX}

\section{Notation}

E Young's modulus of elasticity (MPa)

SI stress intensity at gauge location at hub centre/hub fillet/pipe (MPa)

SIBI stress intensity at gauge location at inside node of bolt (MPa)

SIBO stress intensity at gauge location at outside node of bolt (MPa)

SY axial stress at gauge location at hub centre/hub fillet/pipe (MPa)

SYBI axial stress at gauge location at inside node of bolt (MPa)

SYBO axial stress at gauge location at outside node of bolt (MPa)

MSI maximum stress intensity at hub centre/hub fillet (MPa)

MSY maximum axial stress at hub centre/hub fillet (MPa)

MSIB maximum stress intensity in the bolt (MPa)

MSYB maximum axial stress in the bolt (MPa)

PS principal stress at gauge location at hub centre/fillet (MPa)

AS allowable stress of flange/pipe (248 MPa)

ASB allowable stress of bolt $(640 \mathrm{MPa})$

ES experimental principal stress at gauge location at hub centre/hub fillet/pipe (MPa)

ESBI experimental axial stress in bolt at inside gauge $(\mathrm{MPa})$

ESBO experimental axial stress in bolt at outside gauge $(\mathrm{MPa})$

DP design pressure (15.3 $\mathrm{MPa})$

PT proof test pressure (23 MPa)

YS yield stress of flange (372 MPa)

FID flange inside diameter ( $\mathrm{mm})$

FOD flange outside diameter ( $\mathrm{mm})$

SG strain gauge

$v \quad$ Poisson's ratio

$\sigma_{1} \quad$ hoop stress (MPa)

$\sigma_{2} \quad$ axial stress $(\mathrm{MPa})$ 